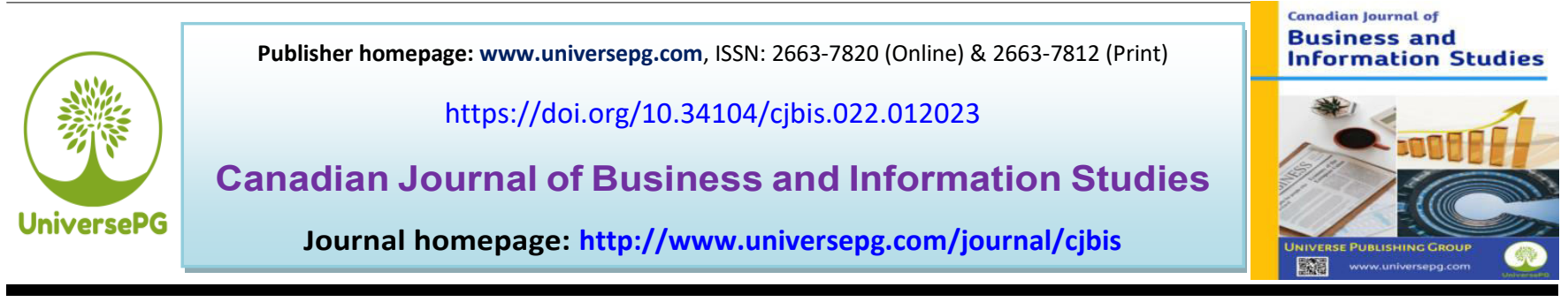

\title{
Measuring the Impact of Corporate Social Responsibility on Customer Satisfaction: Insight from Cumilla City Areas
}

\author{
Md. Mosharraf Hossain ${ }^{1}$, Mohammad Omar Faruq ${ }^{2}$, and Khadiza Sharmin ${ }^{3}$ \\ ${ }^{1}$ Dept. of Management Studies, Comilla University, Cumilla-3506, Bangladesh; ${ }^{2}$ Dept. of Accounting \& Information System, \\ Comilla University, Cumilla-3506, Bangladesh; ${ }^{3}$ Dept. of Accounting, National University, Bangladesh. \\ *Correspondence: mosharrafhossain91@yahoo.com (Md. Mosharraf Hossain, Assistant Professor, Dept. of Management \\ Studies, Faculty of Business Studies, Comilla University, Kotbari, Comilla-3506, Bangladesh).
}

\begin{abstract}
Corporate social responsibility (CSR) has gotten a lot of study attention in the recent decade as a reflection of accompany's beliefs and ethics. Consumer happiness is a growing area of research in this field. The study's goal is to learn how to measure the impact of corporate social responsibility on customer satisfaction in Cumilla city areas. The investigation gathers information from 150 banking customers in a personal interview using a structured questionnaire with five-point Likert scales from customers who have got service from a certain bank in Cumilla, Bangladesh. Data is gathered from customers and entered into an excel spreadsheet for analysis. Different forms of factor analysis are used to assess it. According to the findings of the survey, providing possibilities for rootless children to receive an education is more important than any other industry in terms of key variables that have a substantial impact on customer satisfaction. As a result, it is advised that the study raises awareness among potential customers, researchers, academicians, government officials, businessmen, legislators, and all other stakeholders, and that the banking industry benefit from knowing the elements that influence customer happiness.
\end{abstract}

Keywords: Corporate Social Responsibility (CSR), Consumer satisfaction, and Cumilla region.

\section{INTRODUCTION:}

New behaviors and models are frequently required for corporate survival in today's society. Flexible, customer-focused businesses are the way of the future. Sustainable development, as well as corporate social responsibility (CSR) as a strategy and supply chain tool, has gotten a lot of attention in recent years as a result of increased globalization. In 1983, the UN organized the Brundtl and Commission, which issued the report "Our Common Future," which defined the widely accepted definition of sustainable development as "meeting the requirements of the present without jeopardizing future generations' ability to fulfill their own needs." Economic, social, and environmental UniversePG I www.universepg.com development is the three pillars that support the term. Sustainability has since become a general term used in a variety of contexts to reinforce the perspective that economic, social, and environmental challenges are inherently intertwined and must be addressed as a whole. Banks occupy a unique position in the economy, as their financing activities have the potential to influence production, business, and other economic activity, potentially polluting the environment. Sustainable banks influence the socially responsible behavior of other businesses in addition to improving their own standards. The business model of a sustainable bank is based on the triple bottom line approach. Through CSR and Green banking, sustainable banks 
combine this approach by concentrating on people, planet, and prosperity all at once. Since then, CSR has progressed from giving to controlled behaviors and instrumentality, or strategic CSR. Corporations are increasingly being pressed to comply with environmental standards and transparency, and the market is flooded with competitors in the new millennium, necessitating the usage of CSR as a survival and efficiency strategy (Glan, 2006; Surroca and colleagues, 2009).

The emphasis of CSR conceptual review and empirical studies has switched from ethics to performance in this era, and the level of analysis has shifted from the macro-social to the organizational level. The driving premise of CSR in the new millennium is "doing good to do well" (Rosamaria \& Robert, 2011). Many organizations have turned to CSR to obtain a competitive advantage. Corporate social responsibility (CSR) has gained in prominence in recent years. CSR and branding are linked in several ways, including trust, business reputation, and consumer attribution. Many academics, scholars, and academicians have demonstrated that corporate social responsibility (CSR) has a favorable impact on customer loyalty (Bari et al., 2021; Yusof et al., 2015).

According to McDonald \& Lai, (2010) in to-day's competitive and greener market world, Corp-orate Social Responsibility (CSR) has emerged in Bangladesh over the last few years and is definitely regarded as a strategic corporate tool for conducting business globally, in addition to benevolent social actions. They proposed that customer attributes like awareness of CSR programming and personal judgment, as well as corporate qualities like reputation, influence branding outcomes. According to Rashid and colleagues, (2013) as a consequence, the way consumers view CSR activities is affected by the fit between CSR efforts and the corporation\& brand.

Aside from this continual technological advancement, the information technology revolution has compelled banks to implement e-banking operations in order to maintain their long-term viability in an increasingly competitive environment. Technology is facilitating a geometric increase in the volume of cross-border trading and other financial activity. Financial transactions and banking processes have become faster and UniversePG I www.universepg.com easier thanks to e-banking. Commercial banks are seeking for improved ways to give better service to their customers in order to stay competitive.

According to Mirabi and colleagues, (2014) the CSR activities and consumer loyalty model offered by (Khan et al., 2014) were used in this analysis. The goal of this research is to discover how customers perceive CSR activities and how they affect customer loyalty. As a result, the goal of this research is to look into the impact of customer centricity, environmental stewardship, ethical behavior, and charity as CSR aspects on customer loyalty. This study intends to achieve the research aim and objectives by suggesting and testing structural links between the five constructs: to investigate customers' impressions of the financial sector in terms of purchaser centricity, environmental stewardship, ethical behavior, and charitylook at the effect that customer centricity, sustainable environment, moral behavior, and giving back have on loyalty; to ascertain the factor that has the greatest influence on loyalty.

The study's major goal is to find out how to measure the impact of corporate social responsibility on customer satisfaction in Cumilla city areas. The study's specific goals include: Analyzing the Factors Influencing Customers by Banking Industry CSR; examining the most effective benefits of Banking Industry CSR that can attract customers; Exploring Banking Industry Relationship Strategies; and Making some recommendations for improving the Banking Industry's performance of CSR system.

\section{Literature Review}

CSR was first introduced in the nineteenth century in the United Kingdom. Nonetheless, the United States was the focus of increased interest in CSR in the 1960s and 1970s. CSR's scope was broadened in the 1980s to encompass corporate goals as well as the business's communal obligation, holding it accountable to care for employees, people, and the environment while also making a profit. Satisfying the requirements of stakeholders will help the business and stakeholders to establish a solid foundation for moving forward successfully with best sustainable practices. Effective communication between a firm and its employees can assist the corporation in meeting its enormous obligation of achieving the best economic and environ- 
mental performance possible both inside the company and in society (Kakabad, 2005; Payny \& Raiborn, 2001) reasoned that without sustainable development, "both society and business will not have a long-term future." As a result, the Brundt land definition was widely adopted to strengthen the framework for sustainable development. Mathews asserts that (1985) the providing of financial and non-financial information relating to an organization's physical and social surrounddings is characterized as CSR. According to (Fasanya \& Onakoya, 2013) the affiliation between CSR \&financial performance was explored, and it was determined that CSR could bebeneficial tool for any organization's financial development, and that profit, not morality, is at the core of the existing developing trends in corporate social responsibility practice. Strong CSR performance, according to the research, might go a long way toward improving a company's financial performance in Nigeria. The effect of Islamic Corporate Social Responsibility disclosure on corporate reputations and firm performance was investigated, and it was discovered that there were significant positive relationships between the extent of ICSR disclosure and corporate reputations, between ICSR disclosure and firm performance. Furthermore, the results disclosed that management is proactively carrying out and publishing ICSR measures that meet the needs of a wide span of stakeholders. These findings also provided additional evidence that CSR enterprises\& disclosure from an Islamic standpoint are both crucial business practices for organizations seeking long-term better performance. Arshad and colleagues, (2012); Samina asserts that, (2012) the study revealed that almost all of the sample Islamic banks in Bangladesh implement the required forms of CSR, although the extent to which they participate in the recommended forms of CSR differs. Furthermore, the study showed a strong a favorable link between theamount of CSR spending and the earnings on the savings and investment accounts of the sample Islamic banks. Alam and colleagues (2010) CSR is an emerging concept that allows business leaders to establish and implement self-determined policies to best meet the needs and demands of their stakeholders. It has been recognized that the distinctive nature of CSR practices makes cross-border management difficult. Consistent CSR practices necessitate not only the dissemination of the UniversePG I www.universepg.com
CSR practice, but also the dissemination of its underlying value and purpose across global businesses. Belal asserts that, (2001). A review of various Dhaka Stock Exchange (DSE) listed companies indicated that the vast majority of them provided both mandatory and non-mandatory information. He also claimed that $51 \%$ of businesses failed to provide essential information. He has investigated the subject from the perspectives of politics and history, economics, sociology, and regulatory and institutional difficulties. Finally, he observed that, while many firms provide social disclosures, the amount of information made available is quite restricted. The purpose is to determine the importance of the topic, select the topic's primary needs, gather information from the researched literature, provide proof for various assumptions, and finally study various theoretical parts of the topic. This study's literature evaluation is presented by utilizing certain relevant data from five private banks. There are just a few publications on the subject of CSR in the banking business. It is impossible to overestimate the significance of those writings (Cacioppe and colleagues, 2008).

As corporations become more aware of the broad duties of responsibility implied by their stake-holders' non-financial expectations, the role of CSR as a mechanism for satisfying such commitments becomes increasingly important. Gray and colleagues (1996); Bowen asserts that (1953) CSR is defined in his book 'Social Responsibilities of the Businessman' as a commitment to pursue policies, make judgments, or follow lines of action that are desirable in terms of our society's objectives and values. In his definition, Carroll, (1979) emphasized that social obligations are committed not only for the profit of the company, but also for the benefit of society as a whole. This indicates that by virtue of their existence, organizations have engaged into a social compact requiring them to consider the interests of society when making decisions. He created a conceptual model that incorporates all critical aspects of corporate social performance. He addressed three major issues with the paradigm that both academics and management were concerned about: (1) what does corporate social responsibility involves exactly? (2) What societal issues must the organization address? And (3) what is the organi- 
zation's ideology or form of social responsiveness? According to Wartick and Cochran, (1985), the growth of the corporate social performance model was traced by concentrating on three obstacles to the corporate social responsibilityconcept: economic responsibility, public accountability, and social responsiveness. They also investigated social issue management as an aspect of corporate social responsibility. Their findings suggest that the corporate social performance model is effective for analyzing business and society, and that it provides the foundation for a paradigm for the subject. According to Turban \& Greening, (1996), many businesses strive to ensure that their employees feel connected to their company in order to maintain a low turn-over rate. A positive CSR reputation can help you achieve this goal by attracting the attention of both existing and potential employees. Within the business community, there is a rising acknowledgment of the importance major stakeholders place on socially, environmentally, and ethically responsible behavior by businesses (Zadek et al., 1997). According to Green Paper, (2001) CSR is a voluntary concept in which firms incorporate social and environmental concerns into their company operations and interactions with stakeholders.It also demonstrates that CSR has internal dimensions like as human resource management, workplace health and safety, change adaptability, and Management of natural resources and environmental impact External components include local comm.unities, enterprises, partners, suppliers, and customers, as well as human rights and global environmental problems. According to Harma, (2011) in a paper titled CSR Practices and CSR Broadcasting in the Indian Banking Sector, CSR recognizes an organization's commitment to operate in a socially responsible manner. Poor-country CSR projects, on the other hand, are not very healthy. There are no strict laws governing CSR compliance and reporting, especially in the banking sector. Curtis, (1998) examined the 500 largest publicly traded corporations in the United States that pledge to their stakeholders that they will follow an ethical code when dealing with their interests. The researcher studies this size of organizations for the first time, and the results show that the financial performance of companies that declare their commitment to ethics in their reports exceeds those who do not disclose or make no mention to ethics. According to their UniversePG I www.universepg.com findings, the majority of banks in Bangladesh are unaware of CSR reporting, and no research has been undertaken to provide a conclusive response on the matter. They also noted that CSR reporting is gaining popularity in other regions such as Asia, Europe, Latin America, and North America (Khan and colleagues, 2011).

"CSR is a hazy and ethereal concept that can mean anything to anyone, and hence is successful without meaning," writes Frankental, (2001). CSR, on the other hand, is defined by the European Communities Commission (2001) as "a voluntary concept in which businesses incorporate social \& environmental anxieties into their commercial operations and stake-holder relationships." According to Wood, (1991), "the core premise of CSR is that business and society are interwoven rather than isolated entities," and "CSR is about how firms manage the business process to have an overall constructive influence on society" (Mallenbaker believes, 2006). According to Ernst \& Young, 2002), there are five key reasons why organizations should prioritize CSR. (1) increased stakeholder awareness of business ethical, social, and environmental behavior; (2) direct stakeholder demands; (3) investor pressure; (4) peer pressure; and (5) a greater feeling of social responsibility. According to "Banking Reputation and CSR: a stakeholder value approach," CSR is a significant reputation generator capable of creating economic value over time. In their analysis, the authors found a relationship between CSR and business standing (Trotta and colleagues, 2011). According to Islam et al. (2005), in a study of 48 companies on Corporate Environmental Disclosure in Bangladeshi Public Limited Companies, only $40 \%$ of the companies surveyed included environmental information in their annual reports for the year (2003) that was more general and descriptive in nature. According to the poll, only $16 \%$ of firms have included environmental information in their annual reports under a separate title. According to Imam, (2000), the popular of Bangladesh's publicly merchandizedcorporations did not provide CSR information in 1996-97. Some progressive businesses provide some information, but it is insufficient to satisfy social responsibilities and is qualitative in nature, with a low level of disclosure. As a result of socioeconomic progress and social advancement, corporate social 
responsibility (CSR) has received significant public attention in current years. Consumers are more interested with whether enterprises contribute to societal improvement (Wul \& Wang, 2014). CSR is viewed as an importing component from the West in Asia, and so has a variety of uses from an Asian perspective (Fukukawa, 2009). Based on data from countries including Japan, Malaysia, Indonesia, and Thailand. With the exemption of Japan, these countries, according to Fukukawa, are lagging behind in footings of CSR. However, he believes that in order to survive in the face of intense globalization, these countries must embrace western led CSR. A careful study of the current literature on CSR in developing nations exposed that the notion of CSR in emerging countries has yet to be effectively appreciated and developed (Jhatial et al., 2014). A rising collection of academic and research expertise, according to Jhatial and his colleagues, advocates for a greater considerate of the diversity of CSR policy and repetition in developing countries. These authors underline the significance of researching CSR in emerging countries because they represent the gateway to new commercial prospects (Babbie asserts that, 2007). Although CSR is still in its infancy, it does not yet resemble a theory, which is a collection of interconnected statements intended to explain a specific aspect of social life. The social contract is the basic belief of the legitimacy theory (Guthrie and Parker 1989; Mathews 1993; Patten 1992). According to Deegan (2002), the most frequently accepted theory is legitimacy model, which provides useful insights into corporate social responsibility reporting and disclosure methods. On the additional side, it was argued that a metric system based exclusively on management assessment is only concentrated on the organization's goals and interests; hence, a partnership-based approach is more appropriate by taking employees' participation in performance assessments into account. CSR events can be implemented successfully if all stakeholders' needs are met, which necessitates a good working cycle in an organization between the corporation and the stake-holders. Furgus and Rowney, (2005) created a semantic structure that defined the terminology and reasoning reasons for sustainability, as well as its three scopes of social, economic, and environmental sustainability. According to Dusuki (2006), in order to attain a modest advantage over UniversePG I www.universepg.com conventional banks, Islamic banks should include CSR guidelines into their operations and decision-making. According to the poll, Islamic banks may produce significant resources in footings of reputation, longterm standing, and loyalty from a diversity of stakeholders by attractive in CSR operations successfully and efficiently. Furthermore, Islamic banks' CSR reputation may benefit them in the long run by improving their brand, differentiation, goodwill, quality personnel retention, and, finally, profitability and industry sustainability. Muslim business-people are led by the Muslim Businessman Society (MBS) and are actively supported by the government via Islami Bank Bangladesh Limited. There are currently eight Islamic banks in Bangladesh (plus one foreign Islamic bank) that conduct banking operations based on 'Islami Shariah' principles such as profit-loss sharing. Many traditional banks are already providing Islamic banking services in a variety of diverse locations across the country. Nearby is no mandatory statutory requirement for CSR at the moment and the administration of Bangladesh has neither enforced nor suggested any requirements for CSR performance disclosure. The Bangladesh Companies Act of 1994 and the Banking Companies Act of 1991 establish a general framework for company economic reporting; however, no CSR rules exist. Furthermore, the Inter-national Accounting Standards Committee Foundation states that there is no particular Bangladesh Accounting Standard (BAS) for social and ecological broad-casting (IASCF). However, Sobhani, (2015) regarded this study as "superficial and incomplete" because it just provides a brief remark on CSR attempts in Bangladesh. In a later study focusing on annual reports published by large companies, Belal, (2016) discovered that the majority of annual reports produced by companies registered on the Dhaka Stock Exchange \& in the directory of Dhaka's Metropolitan Chamber of Commerce made social disclosures, but only a small volume of evidence was provided, and this information was of a descritive nature. As explanations for this, he cites a lack of statutory obligations for social disclosures, the being of few organized social groups, and lack of social awareness, a lack of corporate culture, and the existence of a relatively new stock market in Bangladesh. Founded on the work of Belal, (2018), Sobhani et al. (2017) undertook a content investigation of 100 companies 
listed on the Dhaka and Chittagong stock exchanges. Sobhani et al. looked into CSR in the areas of human resources, consumer and product, community, environmental, and "general" and discovered that "disclosure status has improved over the last ten years." Naeem and Welford, (2020) conducted a comparative study on CSR consciousness in the framework of sustainable development in Bangladesh \& Pakistan. Finally, despite its immaturity, we may conclude from this literature review that CSR is already established in the collective consciousness of Bangladeshi business people. Though multinationals contribute in CSR as a consequence of the policies of their parent companies, local companies, particularly local financial institutions, are now joining in growing numbers. The fin- dings of a qualitative study on the awareness of stakeholders of CSR conducted in Dhaka in 2009 by Islami Bank in the healthcare sector will contribute to a better understanding of how CSR is perceived in Bangladesh by presenting the findings of a qualitative study on the perception of stakeholders of CSR conducted in Dhaka in 2009 and explored the views of a diverse group of stakeholders in relative to CSR. According to the CSR literature, CSR not only harms a company's goodwill and reputation, (Trotta et al., 2012). Although there is no formal definition of CSR, it does provide various benefits to the banking business. CSR arose as aidea in the 1960s, based on the supposition that diverse organizations have responsibilities that go beyond their legal obligations.

\section{Research Model}

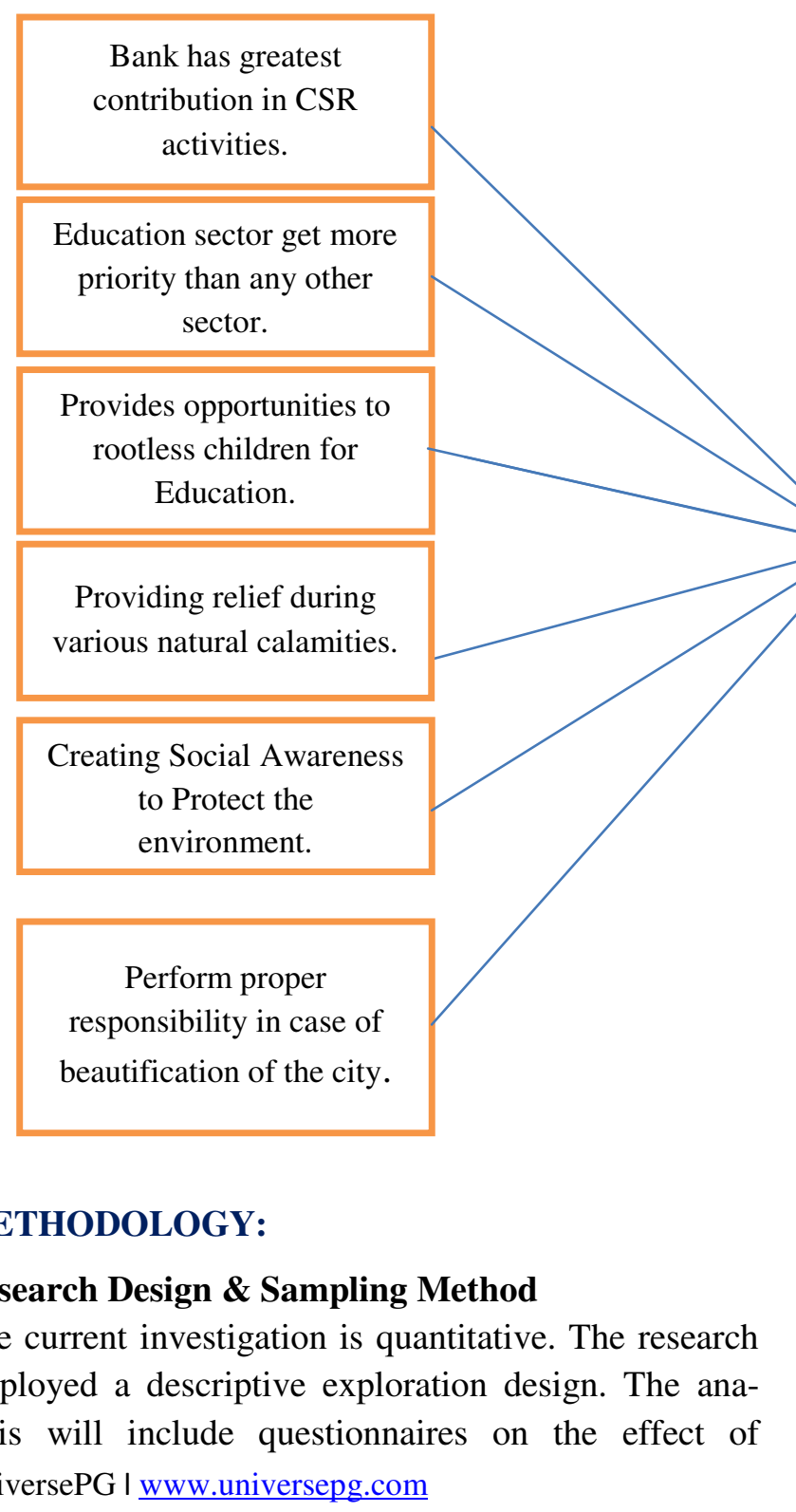

Corporate Social Responsibility on Customer Satisfaction, with an emphasis on descriptive categories and the goal of collecting primary data. The probability sampling method was utilized in the investigation (Systematic sampling method).

Fig. 1: Conceptual model.

\section{METHODOLOGY:}

\section{Research Design \& Sampling Method}

The current investigation is quantitative. The research employed a descriptive exploration design. The analysis will include questionnaires on the effect of UniversePG I www.universepg.com 


\section{Measurement Instrument and Scaling}

Measuring the impact of Corporate Social Responsibility on Customer Satisfaction \& Measuring the Impact On a five-point Likert scale ranging from strong disagreement to strong agreement, respondents were asked to rate their level of agreement or disagreement. A pretest of eight respondents is conducted before the questionnaire is finalized.

\section{Sources of Data}

The investigation makes use of both primary and secondary data. The well-structured comprehensive questionnaire is used to obtain primary data. Several pub- lished articles and reports, a research paper, and several websites are used as secondary data sources.

\section{Data Collection \& Data Analysis}

The investigation gathers information from 150 bank consumers in a personal interview using a structured questionnaire with five-point Likert scales from consumers who have got service from a certain bank in Cumilla, Bangladesh. Data is gathered from customers and entered into an excel spreadsheet for analysis. It is assessed using many forms of factor analysis.

\section{RESULTS AND DISCUSSION:}

\section{Hypotheses Testing}

\begin{tabular}{|c|c|c|c|c|c|c|}
\hline \multicolumn{2}{|c|}{} & \multirow{2}{*}{ Mean } & Std. Deviation & Minimum & Maximum \\
\cline { 2 - 3 } & Valid & Missing & & & & \\
\hline 1 & 150 & 0 & 4.6500 & .65713 & 3.00 & 5.00 \\
\hline 2 & 150 & 0 & 4.4500 & .80873 & 2.00 & 5.00 \\
\hline 3 & 150 & 0 & 4.4000 & 1.02494 & 2.00 & 5.00 \\
\hline 4 & 150 & 0 & 4.6500 & .65713 & 3.00 & 5.00 \\
\hline 5 & 150 & 0 & 4.7000 & .64354 & 3.00 & 5.00 \\
\hline 6 & 150 & 0 & 4.6500 & .57516 & 3.00 & 5.00 \\
\hline
\end{tabular}

Analyses; Bank has greatest contribution in CSR activities

\begin{tabular}{|c|c|c|c|c|c|}
\hline \multicolumn{7}{|c|}{ Bank has greatest contribution in CSR activities } \\
\hline \multirow{3}{*}{ Valid } & Frequency & Percent & Valid Percent & Cumulative Percent \\
\cline { 2 - 6 } & Neutral & 20 & 15.0 & 15.0 & 10.0 \\
\cline { 2 - 6 } & Agree & 40 & 26.0 & 26.0 & 25.0 \\
\cline { 2 - 6 } & Highly Agree & 90 & 49.0 & 49.0 & 100.0 \\
\cline { 2 - 6 } & Total & 150 & 100.0 & 100.0 & \\
\hline
\end{tabular}

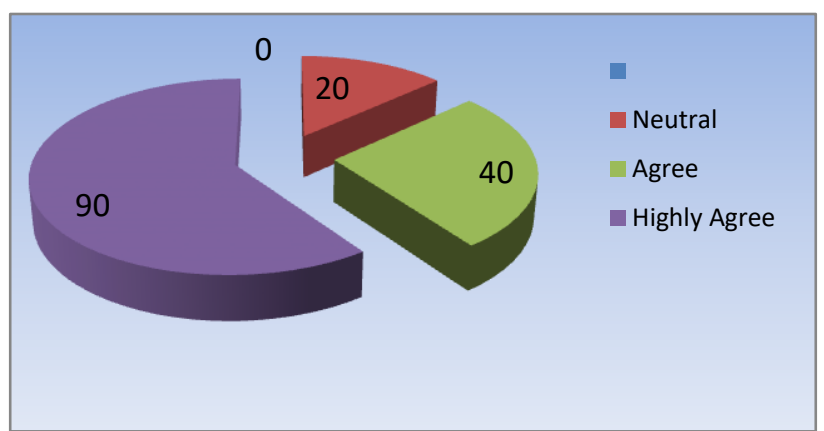

\section{Interpretation}

From the overhead Table, maximum people highly agreed with the statement. They agreed with this state-ment because they think Bank has a better impact on CSR activities. About $90 \& 40$ people signed highly agree \& agree respectively. 20 persons signed neutral who were unaware of this. The mean and standard dev-iation of that question are 4.6500 and .65713 respectively.

Education sector get more priority than any other Sector

\begin{tabular}{|c|c|c|c|c|c|}
\hline \multicolumn{8}{|c|}{ Education sector get more priority than any other Sector } \\
\hline & & Frequency & Percent & Valid Percent & Cumulative Percent \\
\hline & Disagree & 10 & 6 & 6 & 5 \\
\hline Valid & Neutral & 10 & 6 & 6 & 10.0 \\
\hline
\end{tabular}




\begin{tabular}{|c|c|c|c|c|c|}
\hline & Agree & 60 & 40 & 40 & 40.0 \\
\cline { 2 - 5 } & Highly Agree & 70 & 48 & 48 & 100.0 \\
\cline { 2 - 6 } & Total & 150 & 100.0 & 100.0 & \\
\hline
\end{tabular}

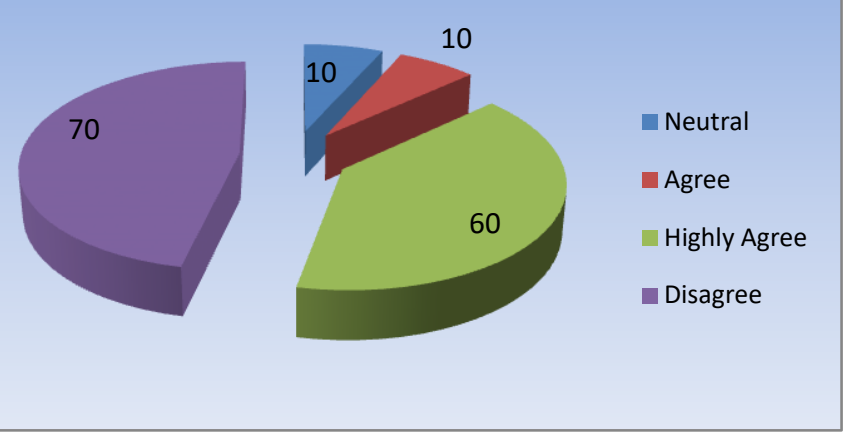

\section{Interpretation}

From the overhead Table, maximum people highly agreed with the statement. They agreed with this statement because they think Bank provide more in education segment than any other Sector. About $70 \& 60$ people signed highly agree \& agree respectively. 10 each persons signed neutral and disagree who were unaware of this. The mean and standard deviation of that question are 4.4500 and .80873 respectively.

\section{Provide opportunities to rootless children for Education}

\begin{tabular}{|c|c|c|c|c|c|}
\hline \multicolumn{6}{|c|}{ Provide opportunity to rootless children for Education } \\
\hline \multirow{3}{*}{ Valid } & Frequency & Percent & Valid Percent & Cumulative Percent \\
\hline & Neutral & 30 & 20.0 & 20.0 & 10.0 \\
\cline { 2 - 6 } & Agree & 50 & 33.0 & 33.0 & 20.0 \\
\cline { 2 - 6 } & Highly Agree & 70 & 47.0 & 47.0 & 100.0 \\
\cline { 2 - 6 } & Total & 150 & 100.0 & 100.0 & \\
\hline
\end{tabular}

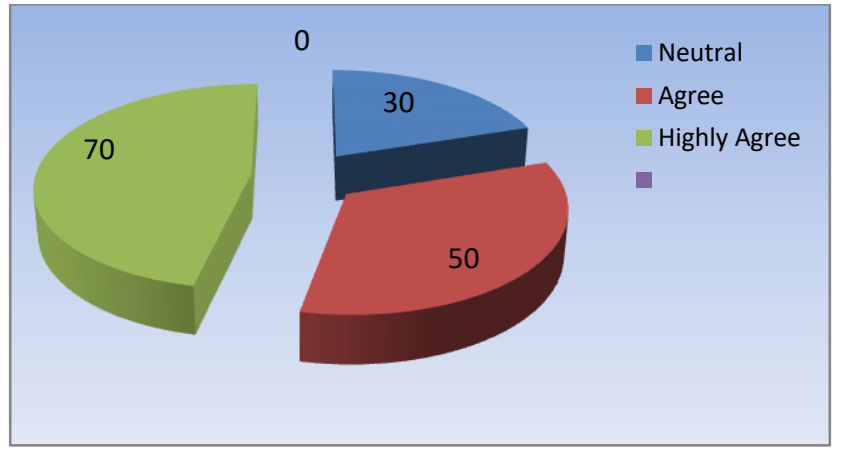

\section{Interpretation}

From the overhead Table, maximum people highly agreed with the statement. They agreed with this statement because Bank provides opportunity to rootless children for Education. About $70 \& 50$ people signed highly agree $\&$ agree respectively.30 persons signed highly disagree who were unaware of this. The mean and standard deviation of that question are 4.7000 and 64354 respectively.

\section{Providing relief during various natural calamities}

\begin{tabular}{|c|c|c|c|c|c|}
\hline \multicolumn{9}{|c|}{ Providing relief during various natural disaster } \\
\hline \multirow{3}{*}{ Valid } & Frequency & Percent & Valid Percent & Cumulative Percent \\
\hline & Neutral & 20 & 13.0 & 13.0 & 10.0 \\
\cline { 2 - 6 } & Agree & 50 & 33.0 & 33.0 & 20.0 \\
\cline { 2 - 6 } & Highly Agree & 80 & 54.0 & 54.0 & 100.0 \\
\cline { 2 - 7 } & Total & 150 & 100.0 & 100.0 & \\
\hline
\end{tabular}

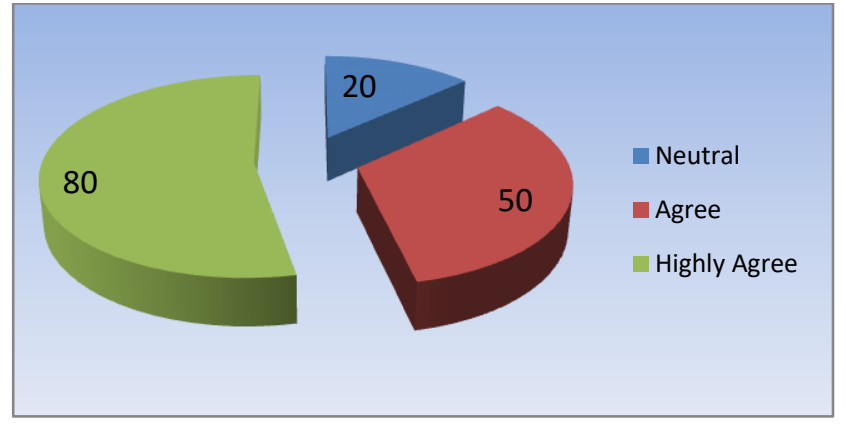

UniversePG I www.universepg.com

\section{Interpretation}

From the overhead Table, 80 people highly agreed with the statement. Those 80 responders think Bank contributed more than any other bank at the spell of natural disaster and provide relief to suffering people sector.50 responders on agree and 20 neutral. The mean and standard deviation of that question are 4.6500 and 65713 respectively. 
Perform proper responsibility in case of beautification of the city

\begin{tabular}{|c|c|c|c|c|c|}
\hline \multicolumn{6}{|c|}{ Perform proper responsibility in case of beautification of the city } \\
\hline & & Frequency & Percent & Valid Percent & Cumulative Percent \\
\hline & Disagree & 15 & 10.0 & 10.0 & 5 \\
\hline \multirow[t]{4}{*}{ Valid } & Neutral & 25 & 16.0 & 16.0 & 10.0 \\
\hline & Agree & 40 & 26.0 & 26.0 & 50.0 \\
\hline & Highly Agree & 70 & 48.0 & 48.0 & 100.0 \\
\hline & Total & 150 & 100.0 & 100.0 & \\
\hline
\end{tabular}

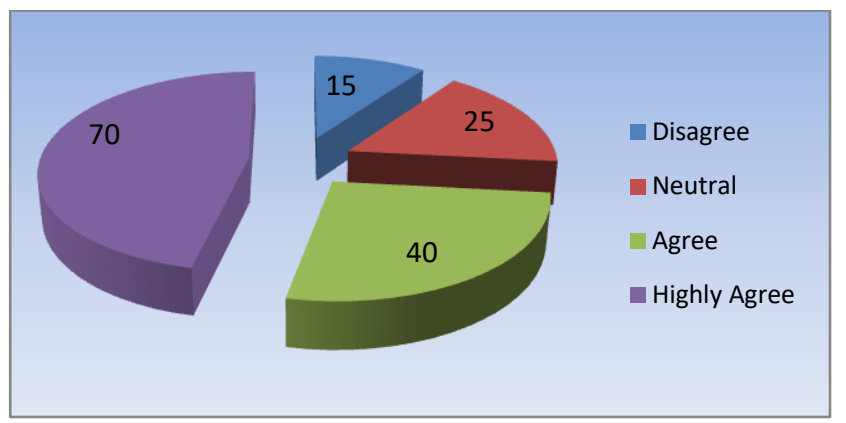

\section{Interpretation}

From the above Table, more the $48 \%$ people highly agreed with the statement. Those 70 responders think bank contributed more than any other instruction in those sector .40 responders on agrees and 25 on neutral and disagree. The mean and standard deviation of that question are 4.3500 and 79614 respectively.

\section{Creating social awareness to protect the environment}

\begin{tabular}{|c|c|c|c|c|c|}
\hline \multicolumn{6}{|c|}{ Creating social awareness to protect the environment } \\
\hline & & Frequency & Percent & Valid Percent & Cumulative Percent \\
\hline & Highly Disagree & 10 & 6.0 & 6 & 2 \\
\hline \multirow[t]{5}{*}{ Valid } & Disagree & 10 & 6.0 & 6.0 & 10.0 \\
\hline & Neutral & 30 & 20.0 & 20.0 & 20.0 \\
\hline & Agree & 50 & 33.0 & 33.0 & 50.0 \\
\hline & Highly Agree & 50 & 34.0 & 33.0 & 100.0 \\
\hline & Total & 150 & 100.0 & 100.0 & \\
\hline
\end{tabular}

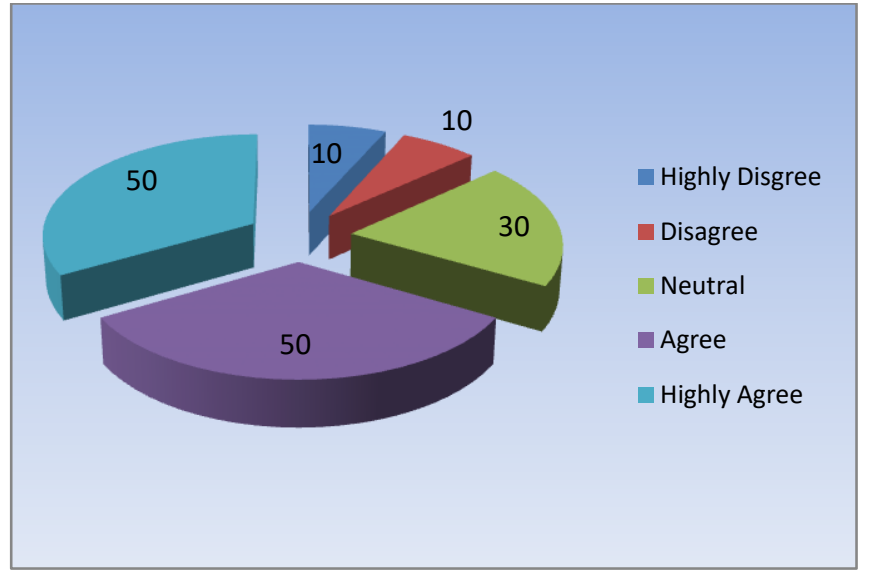

\section{Interpretation}

From the above Table, 50 people highly agreed with the statement. Those 50 responders think bank takes some steps for environment protection .50 responders on agree, 30 neutral 10 disagree and 10 on highly disagree. The mean and standard deviation of that question are 4.1800 and 1.03845 respectively.

\section{CONCLUSION:}

After conducting the survey and analyzing the data, it can be concluded that the banking industry is a corporate social responsible company, with primary motive and environmental sustainability influencing the bank's decision to engage in CSR. Although the bank is involved in CSR, it is a centralized decision, and staff must be well-versed in the processes in order for everyone in the bank to be socially responsible. Bangladesh, as a third-world country, faces numerous challenges. When it comes to correcting all of these problems, the government frequently fines them. Be-cause business owners in this country are considered to be members of the rich class; they can make a greater contribution to the welfare of society. If more businesses, such as the banking industry, stepped forward to aid the community, it would help to build their social branding while also benefiting the community. As a result, we may claim that the banking industry is a corporate 
socially responsible institution, and banks should do even more to improve society.

\section{ACKNOWLEDGEMENT:}

We would want to express our gratitude to all who worked on this aspect of the research study in order for it to be completed successfully.

\section{CONFLICTS OF INTEREST:}

The authors have stated that they have no conflicts of interest in publishing the current study.

\section{REFERENCES:}

1) Alam, S.M.S., Hoque, S.M.S., \& Hosen, M.Z. (2010). Corporate Social Responsibility of Multinational Corporations in Bangladesh: A Case study on Grameenphone. J. of Patuakhali Sci. and Technol. University, 2(1), 51-61. https://mpra.ub.uni-muenchen.de/id/eprint/35496

2) Arshad, R., Othman, S., \& Othman, R. (2012). Islamic Corporate Social Responsibility, Corporate Reputation and Performance. World Academy of Science, Engineering and Technology, 64, 1070-1074

3) Alexander Dahlsrud. (2006). How Corporate Social Responsibility is defined: an Analysis of 37 Definitions, Corporate Social Responsibility and Environmental Management Corp. Soc. Responsible. Environ. Mgmt. 15, 1-13 (2008)

4) Azim, M., Ahmed, E., \& D’Netto, B. (2011). Corporate Social Disclosure in Bangladesh: A Study of the Financial Sector. International Review of Business Research Papers, 7(2), 3755. https://doi.org/10.18034/abr.v6i1.25

5) Brammer, S., \& Millington, A. (2008) Does it pay to be different? An analysis of the relationship between corporate social and financial performance, Strategic Management Journal, 29 (12), pp. 1325-43

6) Babbie, E (2007), the practice of social research, 11th ed. Belmont, CA: Thomson Higher Education.

7) Bari MK, Zaman MH, Mahmud AKMG, and Ghosh SK. (2021). Assertiveness, corporate social responsibility and brand association in anti-globalization era, Int. J. Manag. Account. 3(1), 1-19.

https://doi.org/10.34104/ijma.021.01019
8) Belal, A.R., \& Momin, M. (2009). Corporate Social Reporting (CSR) in Emerging Economies: A Review and Future Direction. $1^{\text {st }}$ South American Congress on Social and Environmental Accounting Research- CSEAR https://doi.org/10.1108/S1479-3563(2009)000000 $\underline{9007}$

9) Bowen, H. R. (1953).Social responsibilities of the businessman. New York: Harper \& Row.

10) Cacioppe, R., Forster, N. \& Fox, M., (2008). A Survey of Managers' Perceptions of Corporate Ethics and Social Responsibility and Actions That May Affect Companies' Success. Journal of Business Ethics, 2(8)

11) Carroll, A. B. (2008). A history of corporate social responsibility: concepts and practices. In A. M. Andrew Crane, D. Matten, J. Moon, \& D. Siegel (Eds.), The Oxford handbook of corporate social responsibility (pp. 19-46). New York: Oxford University Press.

https://doi.org/10.1093/oxfordhb/9780199211593. $\underline{003.0002}$

12) Carroll, A. B., \&Shabana, K. M. (2010). The business case for corporate social responsibility: a review of concepts, research and practice. Intern. J. of Manag. Rev., 12(1), 85-105.

13) Curtis. (1998). A Study of The Link between a Corporation's Financial Performance and Its Commitment to Ethics. Journal of Business Ethics, 17, pp.1509-1516.

14) Carroll, A.B. (1979). A Three-Dimensional Conceptual Model of Corporate Performance. The Academy of Management Review, 4(4), 497-505. https://doi.org/10.2307/257850

15) Dusuki, A.W. (2006). Stakeholders' Expectation towards Corporate Social Responsibility of Islamic Banks. Paper presented in International Accounting Conference III (INTAC 3), IIUM Kuala Lumpur, 26 $6^{\text {th }}-28^{\text {th }}$ June 2006.

16) Ernst andYoung (2002) A Three-Dimensional Conceptual Model of Corporate Performance. The Academy of Management Review, 4(4), 497-505.

17) Frankental, P. (2001). Corporate social responsibility - a PR invention? Corporate communication, 6(1), 1-6. https://doi.org/10.1108/13563280110381170 
18) Fukukawa, K. (2009). Corporate social responsibility in Asia Rutledge.

19) Fasanya,, I. O., \& Onakoya, A. B. O. (2013). Does Corporate Social Responsibility Improve Financial Performance of Nigerian Firms? Empirical Evidence from Triangulation Analysis.

20) Fergus, A. H., \& Rowney, J. I. (2005). Sustainable development: lost meaning and opportunity? Journal of business ethics, 60(1), 1727. https://doi.org/10.1007/s10551-005-2927-9

21) Gray, R., Owen, D., \& Adams, C. (1996). Accounting and Accountability. London: Prentice Hall. https://doi.org/10.4236/tel.2021.115056

22) Goll, I. \& Rasheed, A.A. (2004) the moderating effect of environmental munificence and dynamism on the relationship between discretionary social responsibility and firm performance. Journal of Business Ethics, 49, pp. 41-54

23) Guthrie, J., \& Mathews, M. (1985). Corporate Social Reporting in Australia. Research in Corporate Social Performance and Policy, 7, 251-271.

https://researchers.mq.edu.au/en/publications/corp orate-social-accounting-in-australasia

24) Guthrie, J \& Parker, L (1989). Corporate Social Reporting: a Rebuttal of Legitimacy Theory', Accounting and Business Research, 9(76), pp. 343-352.

25) Gautam, R., \& Singh, A. (2010). Corporate social responsibility in India: a study of top 500 companies. Global Business and Management Research: An International Journal, 2(1), 4156.

26) H. U. Z., Azizul Islam, M., Kayeser Fatima, J., \& Ahmed, K. (2011). Corporate sustainability reporting of major commercial banks in line with GRI: Bangladesh evidence. Social responsibility journal, 7(3), 347-362.

https://ideas.repec.org/a/eme/srjpps/v7y2011i3p34 7-362.html

27) Imam, S. (2000), Corporate Social Performance reporting in Bangladesh, Managerial Auditing Journal, 15(3), 133-141.

28) Islam, S., Hosen, A., Islam, M. (2005), an Examination of Corporate Environmental Disclosure by the Bangladeshi Public Limited
Companies. Pakistan Journal of Social Sciences, 3(9), 1095-1102.

http://www.medwelljournals.com/abstract/?doi=pj ssci.2005.1095.1102

29) Jhatial, A. A., Cornelius, N., \& Wallace, J. (2014). 6 corporate social responsibilities in Pakistan. Corporate Social Responsibility and Local Community in Asia, 111.

30) Kudo, K. (2010). Do your internal organs need to lose weight? Inconspicuous is more dangerous! Visceral fat accumulation is the invisible killer. Taipei: Faces Publishing Ltd

31) Mallenbaker.net (2006). Malaysia: Companies lack awareness of CSR potential (Atastalian). [Online] available:

http://www.mallenbaker.net/csr/CSRfiles/page.ph p?Story_ID $=1372$

32) McDonald, L.M., \& Lai, C.H., (2011).Impact of corporate social responsibility initiatives on Taiwanese banking customers. International Journal of Bank Marketing, 29(1), 50-63.

33) Naeem, M. A., Welford, R. (2009). A comparative study of corporate social responsibility in Bangladesh and Pakistan. Corporate Social Responsibility and Environmental Management, 16(2),108-122

34) Payne, D. M., \& Raiborn, C. A. (2001). Sustainable development: the ethics support the economics. Journal of Business Ethics, 32(2), 157-168.

https://doi.org/10.1023/A:1010726830191

35) Ramasamy, B. and Yeung, M. (2009) Chinese consumer's perception of corporate social responsibility (CSR), Journal of Business Ethics, 88, pp. 119-132.

36) Sobhani, F. A., Amran, A., Zainuddin. (2009). Revisiting the practices of corporate social and environmental disclosure in Bangladesh. Corporate Social - Responsibility and Environmental Management, 16(3a), 167-183. https://doi.org/10.1002/csr.193

37) Samina, Q. S. (2012). Practice of Corporate Social Responsibility in Islamic Banks of Bangladesh. World Journal of Social Science, 2(6), 1- 13.

38) Sharma N., "CSR Practices and CSR Reporting in Indian Banking Sector" International Jour- 
nal of Advanced Economics and Business Management, 1(2), 2011, Pp. 58-66.

39) Turban, D. B., \& Greening, D. W. (1996). Corporate Social Performance and Organizational Attractiveness to Prospective Employees. Academy of Management Journal, 40, 658-672.

40) Trotta, A., Iannuzzi, A., Cavallaro, G., \& Dell' Atti, S. (2012).Banking reputation and CSR: a stakeholder value approach. http://www.repman.com.tr/tr/wp-content/uploads/ user/makaleler/\%20banking-reputation-and-csr-astakeholder-value-approach.pdf

41) Wartick, S.L. and Cochran, P.L. (1985). The Evolution of the Corporate Social Performance
Model. The Academy of Management Review, 10(4), 758-769.

https://www.jstor.org/stable/258044

42) Wood, D.J. (1991). Corporate Social Performance Revisited. The Academy of Management Review, 16(4), 691-718.

43) Wul, S., \& Wang, W. (2014). Impact of CSR perception on brand image, brand attitude and buying willingness: A study of a global cafe. International Journal of Marketing Studies, 6(6), 43-56.

44) Yusof, J.M., Manan, H.A., Karim, N.A., \& Kassim, N.A.M. (2015). Customer's loyalty effects of CSR initiatives. Procardia - Social and Behavioral Sciences, 170 (2015), 109-119.

Citation: Hossain MM, Faruq MO, and Sharmin K. (2022). Measuring the impact of corporate social responsibility on customer satisfaction: insight from Cumilla city areas. Can. J. Bus. Inf. Stud., 4(1), 12-23. https://doi.org/10.34104/cjbis.022.012023 @ @ (- 